\title{
Proceeding
}

9th INSHS International Christmas Sport Scientific Conference, 4-6 December 2014. International Network of Sport and Health Science. Szombathely, Hungary

\section{Physical activities of boys and girls at primary schools in Central Slovakia}

\author{
STEFAN ADAMCAK, PAVOL BARTIK , BORIS CIPOV, JIRI MICHAL \\ Department of Physical Education and Sport, Faculty of Arts, Matej Bel University in Banska Bystrica, Slovakia
}

\begin{abstract}
Adamcak, A., Bartik, P., Cipov, B., \& Michal, J. (2015). Physical activities of boys and girls at primary schools in Central Slovakia. J. Hum. Sport Exerc., 9(Proc1), pp.S345-S353. Our survey deals with the major issues affecting young people, which is the active leisure. We explore the most risky age - boys and girls attending primary school at age 13 to 15 years. By using questionnaire we detect and analyze differences of opinion on the use of physical activities in the leisure time among 808 boys and 797 girls. We found that there are significant differences between boys and girls only in the use of the leisure time pool. From our perspective, the most alarming fact is that $63.5 \%$ of all respondents ( $58.7 \%$ boys and $68.2 \%$ girls) in this age devoted to physical activity in leisure time up to 2 hours per week, what represents only $5 \%$ of leisure time pool per week! This confirms the tendency of reducing young people's interest in movement, which may with the combination with puberty lead to serious health disorders or the orientation to unwanted sociopathic phenomena. Key words: LEISURE TIME, PUPILS OF PRIMARY SCHOOL, PHYSICAL ACTIVITIES.
\end{abstract}

Corresponding author. Department of Physical Education and Sport, Faculty of Arts, Matej Bel University, Tajovského street 40, 97401 Banska Bystrica, Slovakia

E-mail: pavol.bartik@umb.sk

9th INSHS International Christmas Sport Scientific Conference, 4-6 December 2014. International Network of Sport and

Health Science. Szombathely, Hungary.

JOURNAL OF HUMAN SPORT \& EXERCISE ISSN 1988-5202

(c) Faculty of Education. University of Alicante

doi:10.14198/jhse.2015.10.Proc1.24 


\section{INTRODUCTION}

We consider it important to note that on the 4th European Congress FIEP, which took place in 2007 in Bratislava it was managed to incorporate kinetic competence to the eight key competences as part of equivalent education. As a result, movement and physical activity achieved parity status of other individual basic educational areas. At the same time were clearly worded arguments, emphasizing the importance of movement and physical literacy.

To illustrate the value of the concept of physical competence for human life we present its essential characteristic. It is ability to perform the movements in an appropriate form by relation to current or prospective indicator during lifelong development of the individual. It is one of the important indicators of development and personal development, with broad social and health dimension (Bendíková \& Labudová, 2012).

In order to find out what the status of a physical activity in human life is, we came to the conclusion that one of the most important human activities directly related to his being and life. Several authors indicate a deficiency or absence of physical activity as a serious threat to the human organism (Bebčáková, 2012; Michal \& Nevol'ná, 2012). Important and relevant are the opinions of Prusik et al. (2013) who state that a positive attitude towards regular physical activity and related healthy lifestyle must be indoctrinated since youth. The primary need therefore seems requirement that physical activity as much as possible integrates into daily life of students, but also in the everyday life of society. Especially for pupils is needed to achieve such status that they exercise not only during physical education, but also in their leisure time.

Šimonek (2006) recommended for the age group 10-17 years olds daily volume of physical activity in the range of at least three hours. We believe that if we want to make our young people moving in, in terms of healthy development, in the right direction, it should be a daily time devoted to physical activities directly related to the time that was devoted to nonphysical activities. Of course it would be ideal. Sufficient, however, in our opinion would be if at least $50 \%$ of the daily leisure-time was implemented healthpromoting way, and not only among young people but also among their parents.

Compulsory school physical education provides so called basic amount of physical activity of children and youth. Soos et al. (2010) found that the amount of physical activity of pupils cannot be considered sufficient. It is necessary to complement and compensate the deficit with relevant organized sports and physical activities and especially non-organized physical activities either with parents or friends.

An important fact is also that physical activity in addition to regeneration and compensatory function also creates opportunities for self-realization, improving and maintaining physical fitness, induces positive aesthetic and emotional experiences and provides the opportunity to make new friendships and social contacts. This is also confirmed by Frömel \& Bauman (2006).

We can conclude that by the study of the phenomenon, we have found and confirmed by the amount of research and studies of the current period. Biddle et al. (2009), Michal \& Nevol'ná (2012) found the amount of physical activities in adolescent population is really alarming. Interesting are the opinions of Antala (2012) who point out that nowadays cannot be questioned positives of computer literacy and their contribution to globalization and the development of knowledge. 
But in the same place they note as well as Soos et al. (2010), Šimonek (2011), Bebčáková (2012), Adamčák (2013) and others that exactly passive load while using computer along with watching TV, listening to music and others is a major leisure consumption of the current generation of children and youth. The paradox of this situation is that the primary source of information about the possibilities of spending leisure time for young people are their friends and classmates, so the internet is the second most important source of information. The third place where young people can find the information about the activities for leisure time is the school. Disturbing are also data showing the variation of the work and rest for boys and girls. In accordance with the results of nationwide research of children and young people, carried out in $2000-2003$, we can say that $60-70 \%$ of primary and secondary school pupils are not participating at any organized sport activity and significantly less girls than boys are anyhow involved.

This confirms the trend that the number of children in sports is gradually reduced. Bendíková (2009) reported that, compared to 1987 the number was reduced by $30 \%$. For negative she considers particularly the finding that girls (expectant mothers, which significantly affect the lives of their children) were devoted less to physical activity than boys - only half an hour a day.

\section{MATERIAL AND METHODS}

The aim of our research is studying and summarizing theoretical knowledge of the status of physical activities, as a unique area of young people. In addition we implemented the questionnaire to find out what the current views of young people into an active leisure. We focus on the risk category of young people boys and girls at age 13 to 15 years, who through the questionnaires determine the extent and content of physical activities in leisure time and we analyze the gender differences of opinions. The research was realised within the grant projects VEGA 1/0758/14 and VEGA 1/0606/2015.

On the acquisition of theoretical knowledge about the studied phenomenon, we use the method of literature study. In a field survey, to obtain the relevant data used for this area of research, we used most affordable and effective tool - questionnaire method. The survey was conducted on a sample of 1,605 students from 11 primary schools in Central Slovakia.

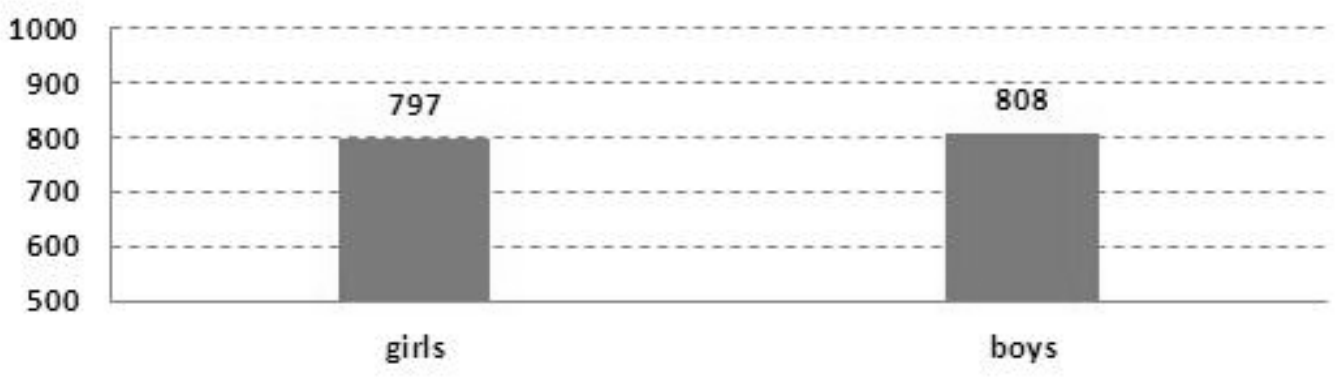

Figure 1. Survey Sample

The survey was distributed at the beginning of the second semester of the academic year 2012/2013. The pupils were given detailed information on how to fill in the questionnaire. To evaluate the results of a survey we used standard quantitative and qualitative methods. Statistical evaluation of the data it was created and processed by the TAP programme provided by the company Gamo, Banská Bystrica. 


\section{RESULTS}

In this section of article we successively evaluate individual responses of interviewed pupils (1605 boys and girls of primary schools of the Central region) to the investigated area.

We focused on the time, structure and character of physical activities. In terms of time devoted to physical activities we focused on finding gender differences in the use of leisure time for physical exercise among boys and girls during the week and the weekend. The rate of daily physical exercise performed during the week is different between the sexes and positive in favor of boys.

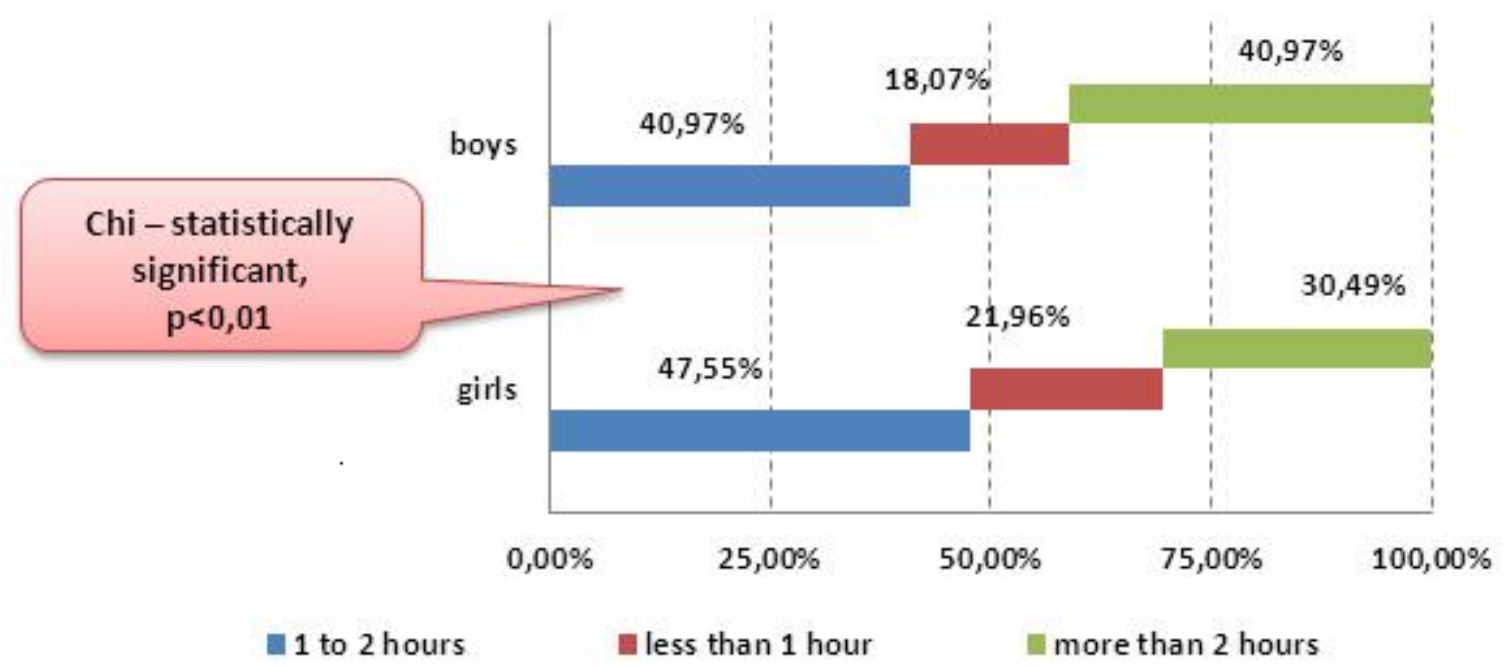

Figure 2. Daily physical activities during workweek

Practically $82 \%$ of the pupils perform physical activities at least $1-2$ hours a day. The situation is less favorable in the group of girls, pointing out their lower daily physical activity. The biggest difference is in the interval of more than 2 hours (10.5\%). Disparity between boys and girls is confirmed by statistics, when we found statistically significant differences in their responses. For a notable negative aspect we consider finding the low amount of time that our respondents state in the realization of physical activities in leisure time, especially if you compare it with the overall average level of free time in the working week (20 hours) in this age group.

To complete the investigation of the time spent for physical activities correctly, we surveyed how much time a day spend boys and girls during the weekend for physical activities. 


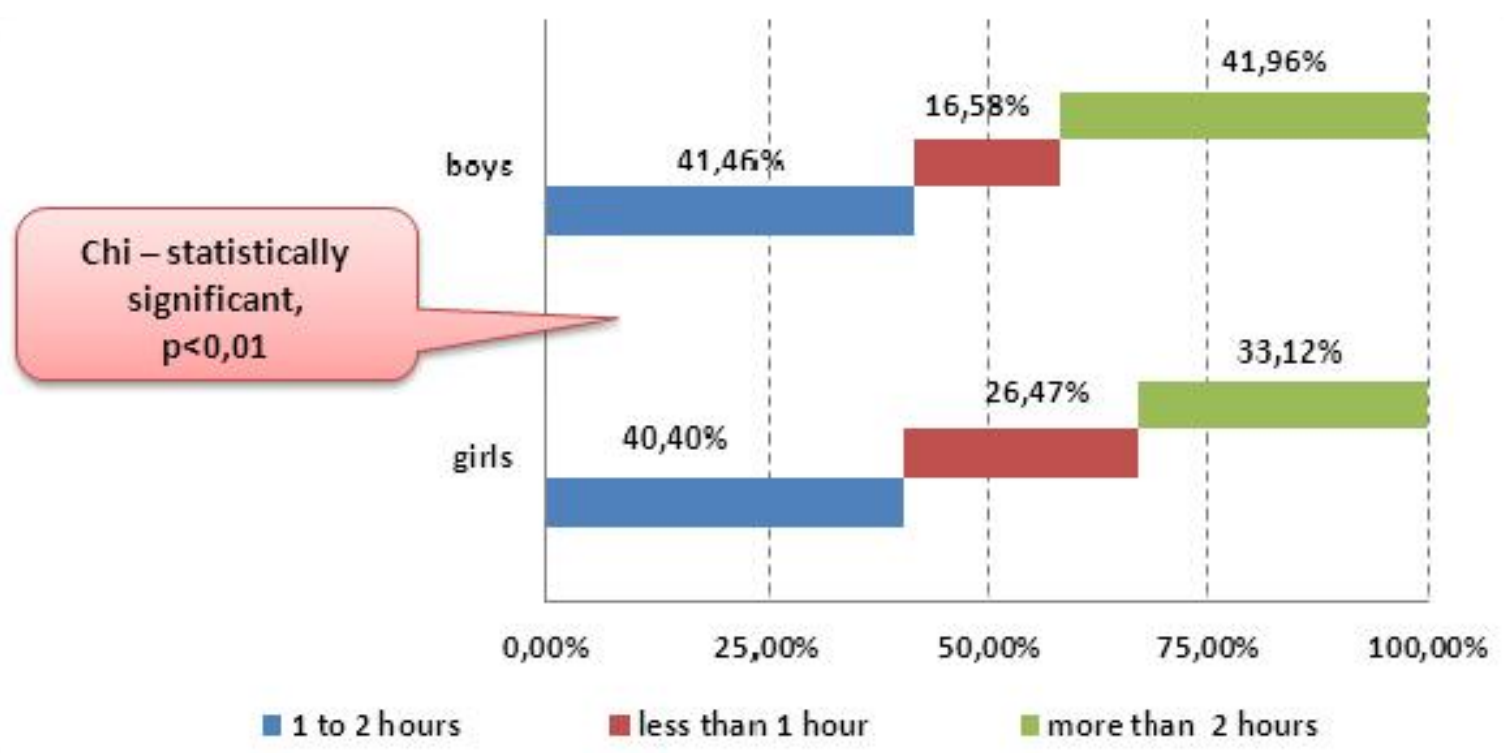

Figure 3. Daily physical activities during weekend

Amount of time devoted to physical activity slightly increased. More than two hours a day perform physical activities $37.54 \%$ of the pupils (an increase of $2 \%$ ). The proportion of respondents who perform physical activity during the weekend between 1 and 2 hours per day has reduced by more than $4 \%$. From the view of gender we found again a difference in the particular interval of more than 2 hours. Statistical significance showed that during the weekend is a significant difference in the approach to the implementation of physical activities in favor of boys, too.

Knowledge of reducing young people's interest in movement and physical activity draw us to the content of realized physical activities. Several studies point to the fact that the team sports, games and playful activities help children at this age to satisfy the desire for human society. They also conclude the children from their loneliness and enable them to communicate with others and therefore these activities are more popular. An important role is played by the fact that students in collective games are teammates, but also opponents, which can collaborate, or compete while they collectively make the game exciting and joyful. These experiences may contribute to the fact that the children simply decide to prioritize physical activity from passive activities (Nemec \& Adamčák, 2013). Among our respondents, we found that the boys and the girls prefer team sports. 


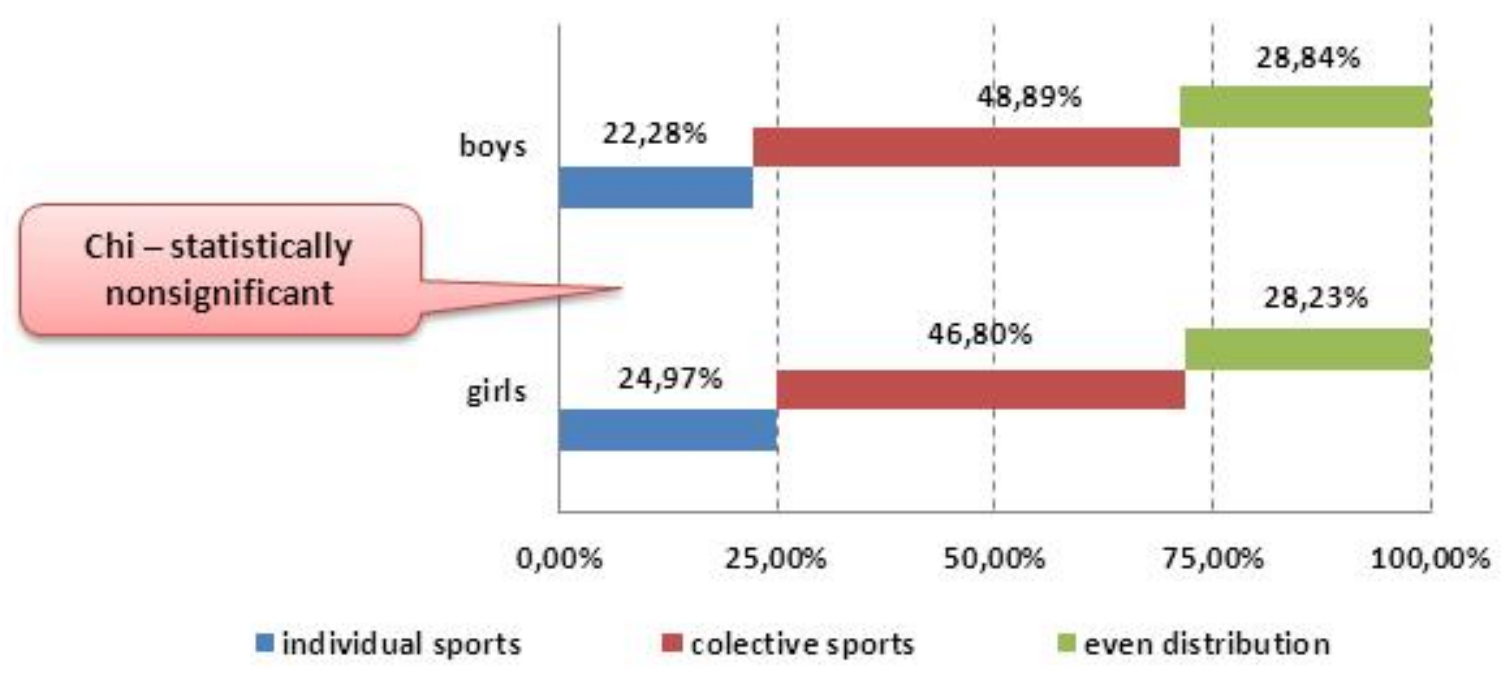

Figure 4. The preference of individual or collective physical activity

For both sexes, it is nearly $50 \%$. From a statistical perspective, the total difference of views on the preference of collective forms of physical activities between the sexes is nonsignificant. This state can be interpreted as an important factor, which should be taken to note even more in the schools. It is clearly confirmed that the children conduct their activities in a group rather than individually.

It is now possible to find an ever stronger tendency to decrease children interests in offers of classically organized leisure activities. As already mentioned in the theoretical part more than $75 \%$ of children do not belong to any organization and activities are carried out independently, resp. with friends. From this perspective, we consider it problematic that the leisure activities of children which are completely unstructured and favorable conditions are not created for them, often do not provide positive realization, relaxation and socialization of the children, and they can lead to passive leisure time and often also lead to socio-pathological phenomena. A similar trend can also be seen in efforts to achieve something.

The current generation of young people has no ambition to make a difference in the overall sense of life, passivity prevails. This is confirmed by the answers of our respondents, which have the highest representation of recreational character of physical activity that is most often realized as disorganized activity. In this issue we also did not detect the statistical significance of differences of opinion on the character of physical activity. Our result that more than $30 \%$ of respondents presented realization of organized physical activity forms focusing on the achievement or sport performance in both sexes and $20 \%$ of even - performance and recreational character, reflects the fact that half of respondents are members of a sports club and want to realize the activity led by coach. We believe that more than half of the children prefer recreational character of the physical activity. By this character is assumed that the movement is not given the right attention and physical fitness and health of children is considered to be a minor part of their leisure-time spending. 


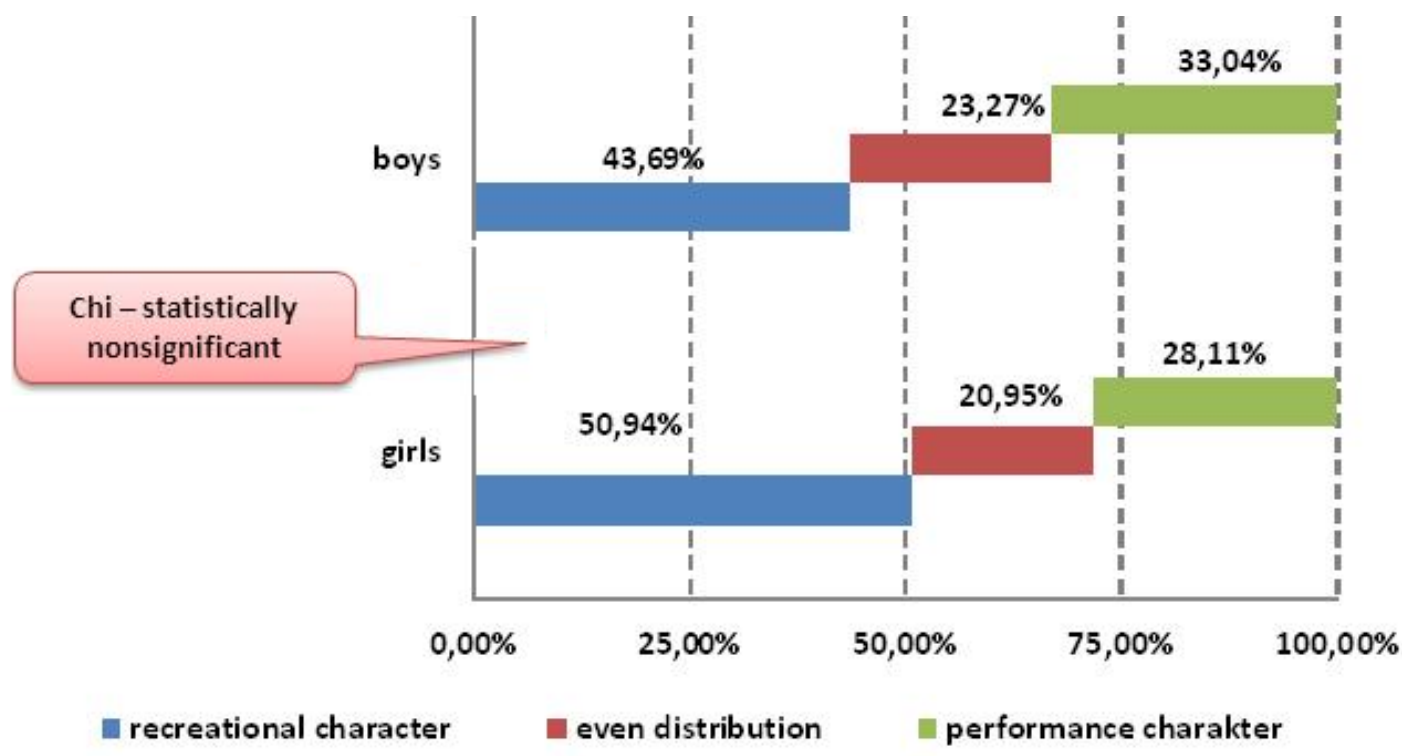

Figure 5. Character of physical activities

\section{DISCUSSION}

Our study has shown some facts about leisure and physical activities of pupils in Central Slovakia. Our findings that indicated less time spent for physical activity than recommended and the difference between boys and girls were not significantly different from the findings of other studies in recent years (eg. Peráčková, 2008; Michal \& Nemec, 2011; Nemec \& Nemcová, 2012; Nevolná, 2013), which focused on the daily routine of pupils. Study by Nader (2008) states that children aged 9-10 years, during the week and weekend performed physical activity more than three hours. With increasing age their activity decreased and at the age of 15 was only about 49 minutes per day of the week. And during the weekend it was even less, only 35 minutes a day.

Our findings did not confirm this trend, even though by the girls is spending of leisure time for physical activities at a significantly lower level than boys. It is positive that our results are closer to recommendations by Šimonek (2006), which states that pupils aged 10-17 years should perform physical activity 3 hours per day respectively. 20 hours per week.

In the last part of our research we found that approximately half of the pupils perform organized leisure-time activity, what does not compare with the findings of Raczek et al. (2002) and Moravec et al.(2007), which additionally highlight the widening gap in the level of physical performance between children who do sports and the children who don't do any sport.

\section{CONCLUSIONS}

Knowledge of the quantity and quality of physical activities of pupils represents potential but also the basis for finding new, positive pedagogical interventions. These interventions shall be oriented to create impulses not only for children but also their parents. In particular, the adults should be a model for children in leisure activities, as they often imitate them and evaluate quality and quantity of their own physical activities according to the behavior and actions of parents. It is necessary to find ways to increase the motivation of pupils for the implementation of the movement into their lifestyle as well as motivation for possibilities of 
taking care for their healthy development. Leisure time is a time when the child shall draw and renew his strength and compensate largely passive character of school load. Current trends indicate that young people do not show an interest in activities that require increased efforts and demands. Movement, physical activities and their character is one of these activities, and it is not always simple to carry out. Therefore, despite the fact that children have during the working day on average 4 hours of free time, they rather rest, while watching television, listening to music or playing computer games. If they still choose some physical activity, it is often carried out individually. We consider the most important that either in the family, school or even sports clubs children shall be motion-formed so that the result was that the use of leisure time will indicate a bullish trend in favor of the motion and a healthy lifestyle. It is necessary to achieve the greatest possible consistency between the cognitive component (knowledge of the importance of movement for health) and conative component (frequency of physical activities) of young people's behavior.

\section{REFERENCES}

1. Adamčák, Š. (2013). Názory a informovanost' žiakov základnej školy v Žiline o globálnom polohovom systéme (gps) a hravých aktivitách s ním spojených (geocaching). Exercitatio corporis motus - salus, 5(2),pp. 65-76.

2. Antala, B. (2012). Telesná a športová výchova v názoroch žiakov základných a stredných škôl. NŠC, FTVŠ UK Bratislava: END, spol. s r.o. Topolčianky,pp.168.

3. Bebčáková, V. (2012). Pohybová aktivita v životnom štýle 14-ročných žiakov prešovského regiónu. Prešov: Prešovská univerzita v Prešove Fakulta športu, pp.71.

4. Bendíková, E. (2009). Kritický pohl'ad na príčiny pohybovej nedostatočnosti slovenských školákov. Tělesná Výchova A Sport Mládeže, 75 (5), pp.2-5.

5. Bendíková, E., \& Labudová, J. (2012). Športové aktivity žien z hl'adiska zdravia a sociálnej inklúzie. Šport A Rekreácia. Zborník Vedeckých Prác. Nitra: UKF PF, pp.12 -17.

6. Biddle, S.J.H., Soos, I., \& Hamar, P. (2009). Physical activity and sedentary behaviours in youth: Data from three central-eastern European countries. European Journal of Sport Science 9, pp.295301.

7. Fromel, K., \& Bauman, A. (2006). Intenzita a objem pohybové aktivity 15-69 leté populace České republiky. Česká kinantropologie 10(2), pp18-26.

8. Michal, J., \& Nevolná, T. (2013). Physical activity as an effective means to a healthy life style. Acta Universitatis Matthiae Belii, Physical Education and Sport, 4(1), pp.103-114.

9. Michal, J. \& Nemec, M. (2011). Vzt’ah žiakov základných škôl k pohybovým aktivitám. Health Education and Quality of Life III. České Budějovice: Jihočeská univerzita, pp.237-242.

10. Moravec, R., Kampmiller, T., Vanderka, M., \& Laczo, E. (2007). Teória a didaktika výkonnostného a vrcholového športu. Bratislava: FTVŠ UK, 2007, pp.240.

11. Nader, P. R. (2008). Moderate-to-vigorous physical Activity From Ages 9 to 15 years, JAMA 300, pp.295-305

12. Nemec, M., \& Nemcová, L. (2012). Športové hry a vol'ný čas detí staršieho školského veku. Exercitatio corporis - motus - salus, 4(2), pp.139-146.

13. Nemec, M., \& Adamčák, Š. (2013). Physical games and education process at the $2^{\text {nd }}$ stage of primary schools. Krakov: Spolok Slovákov v Pol'sku, pp.183.

14. Nevolná, T. (2013). Analýza životného štýlu žiakov základných škôl v regióne Pieštany. Pohybová aktivita, šport a zdravý životný štýl: recenzovaný zborník vedeckých prác. Trenčín: Trenčianska univerzita Alexandra Dubčeka, Fakulta zdravotníctva. 
15. Peráčková, J. (2008). Režim dňa, vol'ný čas a telovýchovná aktivita žiačok vybraného gymnázia. Telovýchovné a športové záujmy v rámci volno-časových aktivít žiakov. Bratislava: Univerzita Komenského, Fakulta telesnej výchovy a športu, pp.160.

16. Prusik, K., Dix, B., lermakov, S., Okninski, J., \& Zukow, W. (2013) Health and recreational values practicing Nordic walking. Journal of Health Sciences, 3(11) pp.259-272.

17. Soos, I., Šimonek, J., Biddle, S., \& Hamar, P. (2010). Pohybová aktivita a sedavý spôsob života východoslovenských adolescentov. Tel. Vých. Šport, 20(2), pp.18-22.

18. Soos, I., Šimonek, J., Biddle, S., \& Hamar, P. (2010). Pohybová aktivita a sedavý spôsob života východoslovenských adolescentov. Tel. Vých. Šport, 20(2), pp.18-22.

19. Šimonek, J. (2006). Športové záujmy a pohybová aktivita $v$ dennom režime a ich vplyv na prevenciu drogových závislostí detí a mládeže. Štúdie III. Nitra: Pedagogická fakulta UKF, pp.7102.

20. Šimonek, J. (2011). Výskumy objemu pohybovej aktivity na školách. Nitra: PF UKF Nitra, pp.71. 